\title{
A LEARNING MODEL DEVELOPMENT OF CRITICAL READING COMPREHENSION THROUGH RECIPROCAL TEACHING
}

\author{
Budiasih \\ aseeh83@gmail.com \\ Fitri Ana Ika Dewi \\ fitriana.kade@gmail.com \\ IAIN Surakarta
}

\begin{abstract}
This research aims at designing a learning model of critical reading based on Reciprocal Teaching. This research is a Research and Development (R\&D) which applies the theory of Borg \& Gall (2007). The subject is the second semester students that consist of 60 students in the academic year of 2017-2018. Data are obtained form interviews of lecturers and students, observation during implementation, and validation notes. The expert judgment was applied to validate the design of the learning model. The final product of the research is a learning model of critical reading by applying the strategy of Reciprocal Teaching consisted of four activities namely summarizing, questioning, clarifying, and predicting which is extended into six activities namely, predicting, questioning, clarifying, self-monitoring, summarizing, and evaluating. The model is considered to be supportive to the critical reading instructional since the students can complete the written tasks successfully.
\end{abstract}

Keywords: reciprocal teaching; learning model; critical reading

\section{INTRODUCTION}

A fluent reader has a potential opportunity to develop the ability to read critically. Since reading requires high thinking process, the reader needs to have some skills to understand a text. Reading critically means reacting with systematic evaluation to what readers have heard and read that requires a set of skills and attitudes (Browne \& Keeley, 2007). Scanlon (2010) and Kennedy (1981) argue that critical comprehensionwhich involves reading critically means evaluating the information in the text relative to what it means to the reader and relative to the intentions, expertise, and/or perspective of the author. Critical reading discovers the implied meanings, interpretsand evaluates the text. Kennedy (1981) explains that the reader is ready to evaluate a text after he has found and understood information (literal reading) and its implied meanings have been discovered and interpreted (inferential reading).
However, some readers often find difficulties in understanding an author's ideas in a text.

The difficulty to comprehend a text is caused by several factors; one of them is the inadequate ability to engage in inferential thinking (Scanlon, 2010). Davies, Nuttall, Urquhart \& Weir in Wallace (2003) also argue that the main problems of foreign language learners are lacking of both linguistic knowledge and cultural setting of authors in their writing. The difficulty to comprehend a text happensto the students of English Education Department of IAIN Surakarta. The failures to read a text critically is caused by their limited knowledge towards the contexts and cultures which are constructed by the author through his writing. The different cultural contexts of the readers and the writers potentially create slower comprehension even failures in making meaning process. Hirsch in Scanlon et al. (2010) states that world knowledge is an essential 
component of reading comprehension, because every text takes for granted the readers' familiarity with a whole range of unspoken and unwritten facts about the cultural and natural world. Scanlon et al. (2010) write that if someone with no background knowledge persists with the reading at all, she is likely to read the text quite passively and with little expectation of understanding.

The problems of the students' failures and difficulties in comprehending and evaluating English texts cannot be disregarded because their problems will block their critical reading skill. Developing a learning model in teaching critical reading comprehension helps learners to improve their critical reading skill. The term of model in language teaching is defined as someone or something which is used as a standard or goal for the learner (Richards \& Schmidt 2002). Joyce, Weil \& Calhoun (2004) write that models of teaching are really models of learning. They explain that these models have many uses, ranging from planning lessons and curriculums to designing instructional materials, including multimedia program.

One of modelsin teaching reading comprehension which is widely used and has great success is ReciprocalTeaching proposed by Palincsar and Brown in 1984. Reciprocal teaching is a learning procedure designed to teach and improve students' reading comprehension. It involves four cognitive strategies in the teaching process, namely summarizing (selfreview), questioning, clarifying, and predictingthrough dialogues between a teacher and students to convey the meaning of the text (Palincsar \& Brown 1984, 117). In reciprocal teaching, every activity has its own function. Summarizing (self-review) is the activity of requesting students to allocate their attention to the major content and checking to see if they have understood the text. Generating questions (questioning) is the activity of students to compose questions on the content and to concentrate on main ideas and to check of the current state of understanding. Clarifying is an activity that students engage in critical evaluation as they read. Predicting concerns with future content that involves them in drawing and testing inferences. All four activities involve activation of relevant background knowledge (Palincsar, Sullivan \& Brown 1984). The supported the idea that to construct the meaning of a written text group of students is collaboratively applying four reading strategies (questioning, clarifiying, summarizing and predicting (Tarchi \& Pinto 2016). .

Reciprocal teaching will foster students to comprehend texts. First, the procedure of the activities provides a relatively natural setting for the teacher to engage in these activities and to provide a model of what readers do when they try to understand and remember texts. Second, reciprocal teaching always forces the students to respond and this gives the teacheran opportunity to provide appropriate feedback to the students' responses.Third, the reciprocal teaching procedure involves continuous trial and error in the classroom learning. Through interaction with the supportive teacher, the students were led to perform at an increasingly more mature level (Palincsar et al. 1984).

Some researchers also regard reciprocalteaching as an ideal model to strengthen reading comprehension. Oczkus (2013) writes that the possibilities for implementation the reciprocal teaching are creative and endless. Reciprocal teaching has strength on discussion technique involves four strategies: predict, question, clarify, and summarize. Lysynchuk, et al. (1990) comes to conclusion that the teaching activities in reciprocal teaching encourage students to comprehend and realize 
information in the text. He applied four steps of activities in the sequence of making predicting, seeking clarification, generating questions and summarizing. Meanwhile, Meyer (2010) argued that reciprocal teaching was successful to increase deep comprehension of text and higher order thinking through student-generated questioning. Meyer extended the four comprehension strategies that traditionally constitute reciprocal teaching which are predicting, clarifying, questioning and summarizing to include orientating, connecting and giving feedback.

Helping learners improving their critical reading skill can be undertaken by teachers through developing a learning model to teach critical reading comprehension. To develop a certain learning model, knowledge and experiences of the teachers are important factors. Developing a learning model can be based on a certain model which is successfully implemented by other teachers to improve students' critical reading skill.

\section{RESEARCH METHOD}

The design of the research is Research and Development (R\&D). Gall, Gall \& Borg (2007)argue that $\mathrm{R} \& \mathrm{D}$ is a model development of the research which is used to design a product and new procedures that is sistematically tested in the field, evaluated, and revised as far as it accomplishes criteria of effectiveness and quality standards. The R\&D of critical reading instructional is conducted by applying 7 steps of development: (1) Needs Analysis, (2) Planning, (3) Developing a Preliminary Learning Model, (4) Preliminary Field Testing of the Developed Learning Model, (5) Revision of the Developed Learning Model, (6) Main FieldTesting of the Developed Learning Model, and (7) Final Product of the Developed Learning Model.

The subject of the research is the second semester students that consist of 60 students in the academic year of
2017-2018. They are around 18 years old. Their English language level is intermediate. Data are obtained form interviews with lecturers and students, observation during implementation, and validation notes. The data which are obtained from observation are classified in the reciprocal teaching's activities that include of predicting, questioning, clarifying, self-monitoring, summarizing, and evaluating. Data are analyzed by applying Interactive Analysis Model of Miles and Huberman in the form of data reduction, data presentation, and drawing conclusion (Sutopo 2002).

\section{RESUlTS AND Discussions}

Adopted from Flemming (1987), there are several basic skills of critical reading activities in the instructional: (a) distinguishing statements of fact and opinion, (b) evaluating author's opinion which consists of justified and unjustified opinion, hasty generalization, dan diversionary tactics (attacking a personal's character or the past, appealing reader's emotion), (c) connotation words, and (d) tone.

Those elements are essential for the reader to evaluate a text because a writer always tries to convince the readers to believe in what he writes. The steps of activities are applied to make sure that the students really comprehend the texts and are able to evaluate them critically. Each activity has its function to foster students' comprehension.

\section{Predicting}

This strategy refers to the expectations about the writers' or the authors' message/messages in the text. In this strategy readers evaluate their prediction while reading the text in order to prove or reject their expectations. This strategy gives opportunities for the readers to guess the content of the text before reading.

\section{Smoking}

It is just not fair for smokers to be allowed to smoke when nonsmokers are 
present; there should be more regulations forbidding people to indulge in smoking if nonsmokers are present. In a recent study, the American Cancer Association has reaffirmed and strengthened its original position on smoking cigarettes. There is a clear-cut link between smoking cigarettes and the incidence of lung cancer. In addition, smokers are three times more likely to get heart disease and emphysema.

Readers relate their background knowledge to the topic, understand it and become able to evaluate it by skimming the given photos and headings. For instance, readers may predict what will be in next paragraph passage (Ismail, 2012). The students are led to the word of 'smoking' and are asked what the paragraph will probably inform the readers. The lecturer can also asks the students whether they are familiar with the word 'smoking'.

\section{Questioning}

The lecturer assists his/her students to find the main key words in the passage in order to answer questions in the text. She will be enabled to ask questions which facilitate high thinking abilities. The lecturer asks students about the main idea in the paragraph. In this strategy students can focus on that information that is more needed in the passage (Ismail 2012). Students ask and answer questions to understand the text. They draw on multiple sources, including digital items, to answer questions (Oczkus 2013).

Related to the passage of Smoking, the lecturer may give question such as: 'What does the text tell about?' or 'What do you know about the text?' This is a way to trigger the students to read quickly and comprehend the text in general. This strategy is to focus on the comprehension. The activity that involves between lecturer and student demands students to be more active in questioning and answering.

\section{Clarifying}

Clarifying is a strategy, where students may re-read the text in order to recognize and understand unfamiliar information. In this process, they may use dictionary or asking help from the teacher to understand the meaning of new idioms, expressions or vocabulary in the text. The lecturer may evaluate the readers' understanding of the main idea in the text (Ismail 2012). They also use context to confirm or self-correct, and they reread when necessary (Oczkus 2013).

The 1979 book, Nim, written by the psychologist Herbert Terrace, should be required reading for all those people who are convinced that chimpanzees can use sign language to 'talk'. It should be required because it places in serious doubt the notion that animals can "talk" like human beings. After four years of teaching Nim, a baby male chimp named for the linguist Noam Chomsky, Terrace wrote an account of his experiments, and that account does not support popular claims for animal language. As Terrace points out in the book, Nim, by himself, seldom used any sign language at all. Instead, he confined himself to responding to his trainers. Fifty percent of the time his signs imitated part or all of his trainer's original signs. In addition, whenever he began to string together more than two or three words, he would become confused and simply repeat signs over And over again, never developing the ability to construct sentences.

In clarifying, the students read the text more carefully and they may discuss their understanding to their friends and the lecturer. This step is to check student's comprehension. The lecturer may evaluate the readers' understanding of the main idea in the text (Ismail 2012). In this activity, the students are asked to make a group of two or three. Each of them should explain their understanding of the text. if they do not come to the same conclusion of understanding, the 
lecturer will help them to lead them into the correct comprehension.

\section{Self-monitoring}

Nation \& Macalister argue that learners can improve the quality of their language use by monitoring themselves. Teachers can help learners with monitoring in several ways. One way is to provide the learners with monitoring goals, namely particular points to monitor. This can be done simply as a suggestion, for example by giving instructionor it can be a list or scale of points to look for in written work.

The lecturer helps the students by giving some clues related to the text, for example some words that the students should really understand the meaning in the context. This is essential to make students sure for their whole comprehension. Some words such as 'required', 'convinced', 'sign', 'language', 'confined', 'imitated' are important to be emphasized in comprehending the text.

\section{Summarizing}

This strategy gives students the opportunity to detect the main important information in the text, organize them and find out the relationships between them. It shows the process of summing up the text and reproducing it in the new words. The students rewrite what the author wanted them to know in the text in a new form briefly. Students can identify main ideas and details in paragraphs (Oczkus 2013, 35).

The students are required to write their comprehension of a using their own words in brief. They may paraphrase the text into a shorter one by retaining the original message of the text. In this phase, it is important for the students to have knowledge of similarity of word meanings.

\section{Evaluating}

The meaning of an evaluation may relate to the effectiveness in the thinking, reasoning or argumentation and in the quality of the representation of the thinking in writing, speech etc. It is an important characteristic of deep critical thinking that the thinker takes a critical (metacognitive) stance towards her actual process of critical thinking and its representation (Moon 2002, 126). Justification and evaluation to texts depend on the reader's accurate analysis to the messages in the texts.

The lecturer trains the students to recognize the writer's argument by asking some questions such as: (a) Is the author technically correct in what he or she says? (b) Has the author documented controversial statements? (c) Is the author qualified to write on this subject? The students should find evidences for any statement that the author writes in the text. It is started by recognizing the statement of fact and opinion, justified and unjustified opinion, diversionary tactics, connotation words, and the tone.

It is just not fair for smokers to be allowed to smoke when nonsmokers are present; there should be more regulations forbidding people to indulge in smoking if nonsmokers are present. In a recent study, the American Cancer Association has reaffirmed and strengthened its original position on smoking cigarettes. There is a clear-cut link between smoking cigarettes and the incidence of lung cancer. In addition, smokers are three times more likely to get heart disease and emphysema.

From the text entitled Smoking, the students should identify which sentence is considered as statement of opinion. The first sentence is considered to be the opinion of the writer. The next step is that they have to recognize whether the writer's opinion is supported by evidences or not. This is important to give judgment whether the opinion is justified or unjustified opinion. The text indicates that the writer's opinion is unjustified since it is not supported by evidences. There is relationship between the argument and the expansion of the opinion. 
In the teaching practices, the procedures of critical reading based on reciprocal teaching are able to activate students' background of knowledge to bridge their comprehension of the text. The extension of activities can lead students to think critically in evaluating a writer's arguments. The steps of activities help students to focus on the comprehension. Reciprocal teaching is successful in fostering students to comprehend a text explicitly and implicly and to evaluate the text critically.

The extension procedures of reciprocal teaching from four into six activities by including self monitoring and evaluating are needed because English foreign language learners need practices both in individual and in group to construct the independency in solving the problems in critical reading activity. Self monitoring helps students strengthen their understanding about certain topic. It is influenced by the target learning outcome is in English which is the second language for them. It may cause misunderstanding around students while they are discussing a topic. Therefore, self monitoring helps them strengthen their understanding by self monitoring and clarifying to their lecturer.

Further, the activity of judgment can be a standard to measure students' understanding about a certain topic. It is implemented through written test which is done individually. Therefore, it reflects students' reading ability in understanding a text. The result of the text becomes a standard reference for lecturer to continue or repeat the topic. When it is needed, lecturer can review back to the difficult part of the topic.

The implementation of reciprocal teaching model in for critical reading learning take longer time than conventional model such as: lecturing. The development model through extension procedures from four activities to six activities take a longer time, because each activity needs long time to be executed. Therefore, to finish a topic take two or three meetings depend on the degree of difficulty of certain topic.

\section{ConClusion}

Model development of critical reading through reciprocal teaching which is implemented to the students of English Education Department results that the teaching practices runs succesfully. The learning activities of reciprocal teaching to teach critical reading are modified by extending the steps and changing the sequences of the activities. The modification is needed to adjust with the learners who are not English natives. The activities are predicting, questioning, clarifying, self monitoring, summarizing, and evaluating. The six activities of learning procedures lead the students to do selfmonitoring towards their evaluation of the text. The learning design creates students' learning collaboration between student-student and studentlecturer. It also builds students' independency in evaluating a writer's arguments in the text. Although, reciprocal teaching model takes a longer time, it makes students easy to understand the content of the text.

\section{REFERENCES}

Browne, MN \& Keeley, SM. 2007. Asking the Right Questions. A Guide to Critical Thinking. New Jersey: Pearson Prentice-Hall

Celce-Murcia, M, Z. Dornyei\&S. Thurrel. 1995. "Communicative Competence: A Pedagogically Motivated Model with Content Specifications". In Issues in Applied Linguistics, 6 (2): 5-35

Flemming, Laraine E. 1987. Reading for Result. Boston: Houghton Mifflin Co.

Gall, Meredith P, Joyce P Gall\&Walter R. Borg, 2007. Educational Research (8th edition). Boston: Pearson Education.

Ismail, Nizam Hairul et al. 2012. "The Role of Reciprocal Teaching Strategy as an Important Factor of Improving Reading 
Motivation”. Elixir International Journal: 11836-11841

Kennedy, Eddie C. 1981. Methods in Teaching Developmental Reading (2nd edition). Illinois: Peacock Publishers.

Lysynchuk, LM et al. 1990. Reciprocal Teaching Improves Standardized Reading-Comprehension Performance in Poor Comprehenders. The Elementary School Journal, 90 (5): 469484

Joyce, Bruce, Marsha Weil \&Emily Calhoun. 2004. Models of Teaching. (7th edition). Boston:Pearson

Meyer, Kylie. 2010. "Diving into Reading: Revisiting Reciprocal Teaching in the Middle Years". Literacy Learning:The Middle Years. 8 (1): 41-52

Moon, Jennifer. 2008. Critical Thinking: An Exploration of Theory and Practice. New York: Routledge

Nuttall, C. 2000. Teaching Reading Skills in a Foreign Language. Oxford: Macmillan Publishers Limited

Oczkus, Lori. 2013. "Reciprocal Teaching: Powerful Hands-on Comprehension Strategy". The Utah Journal of Literacy, 16 (1): 34-38

Palincsar, Annemarie Sullivan \& Ann L. Brown.1984. Reciprocal Teaching of Comprehension-fostering and Comprehension-monitoring Activities. Cognition and Instruction. 1 (2): 117 175
Richards, JC \& R. Schmidt, 2002. Longman Dictionary of Language Teaching and Applied Linguistics. Harlow: Pearson Education Limited

Scanlon, DM. et al. 2010. Early Intervention for Reading Difficulties: The Interactive Strategies Approach. New York: The Guilford Press

Stern, HH. 1983. Fundamental Concepts of Language Teaching. Oxford: Oxford University Press

Sugirin. 2002. The Comprehension Strategies of Above Average English as a Foreign Language (EFL) Readers. Dissertation. Victoria: Deakin University

Sutopo, HB. 2002. Metodologi Penelitian Kualitatif. Surakarta: Sebelas Maret University Press.

Tarchi, Christian \& Giuliana Pinto. 2016. "Reciprocal teaching: Analyzing Interactive Dynamics in the CoConstruction of a Text's Meaning". Journal of English Teaching for a Purpose. 1 (1)

Wallace, Catherine. 2003. Critical Reading in Language Education. New York: Palgrave Macmillan

Westwood, Peter. 2001. Reading and Learning Difficulties: Approches to Teaching and Assessment. Victoria: The Australian Council for Educational Research Ltd. 